GRASAS Y ACEITES 71 (3)

July-September 2020, e363

ISSN-L: 0017-3495

https://doi.org/10.3989/gya.0456191

\title{
Effect of leaf and fruit extracts of Schinus molle on oxidative stability of some vegetables oils under accelerated oxidation
}

\author{
A.F.N. Volpini-Klein ${ }^{a}$, C.A.A. Silva ${ }^{a}$, S.S.L. Fernandes ${ }^{a}$, C.L. Nicolau ${ }^{a}$, C.A.L. Cardoso, \\ A.R. Fiorucci ${ }^{\mathrm{a}}$ and E. Simionatto ${ }^{\mathrm{a}, \mathbb{}}$ \\ ${ }^{\text {a}}$ Programa de Pós-Graduação em Recursos Naturais, Universidade Estadual de Mato Grosso do Sul, \\ 79950-000 Dourados and Naviraí-MS, Brazil \\ ${ }^{\square}$ Corresponding author: eusimionatto@yahoo.com.br
}

Submitted: 23 April 2019; Accepted: 14 June 2019; Published online: 23 July 2020

\begin{abstract}
SUMMARY: The most highly recommended oils for the diet are those which are rich in unsaturated fatty acids. However, the presence of these components in the oils is related to oxidation, which can be determined by the induction period. Further safety and the prolongation of the storage period for such oils can be achieved by the addition of efficient antioxidants, which today are preferably from natural sources. In order to contribute to the related research, the main objective of this study was to evaluate the efficacy of Schinus molle extracts compared to synthetic antioxidants (BHT) in delaying the oxidation of some vegetable oils. The results of the present study showed that the fruit and leaf extracts of Schinus molle presented activities and potential for being used as antioxidants in vegetable oils based on the tested methods (DPPH and ABTS). The extracts were also characterized as containing phenolic compounds by the Folin Ciocalteau method and by high performance liquid chromatography (HPLC). The action of the extracts as natural antioxidants was proven in the vegetal oils of chia (Salvia hispanica) and peanut (Arachis hypogaea) by the Rancimat method. It was observed that the oils increased their resistance to oxidation when incorporated with the extracts of Schinus molle, and the extract from the leaves increased the induction period of peanut oil by more than three hours (from 19.5 to 22.9 hours) with an extract concentration of $2.5 \%$. The fruit extract was more efficient in delaying the oxidation of chia oil, prolonging its induction period by more than one hour with a concentration of $2.5 \%$ (from 3.1 to 4.3 hours). According to the results, the extracts of Schinus molle have favorable properties for possible use as an additive which inhibits the oxidation process of the tested vegetables oils.
\end{abstract}

KEYWORDS: Hydroalcoholic extracts; Oxidative stability; Rancimat; Schinus molle; Vegetable oils

RESUMEN: Efecto de extractos de hojas y frutos de Schinus molle sobre la estabilidad oxidativa de aceites mediante oxidación acelerada. Los aceites más recomendados para la dieta son los ricos en ácidos grasos insaturados. Sin embargo, la presencia de estos componentes está relacionada con la oxidación del aceite, que puede determinarse por el período de inducción. La seguridad adicional de tales aceites y la prolongación del almacenamiento se pueden lograr mediante la adición de antioxidantes eficientes, que hoy en día se prefieren los provenientes de fuentes naturales. Para contribuir con estas investigaciones, el objetivo principal de este estudio fue evaluar la eficacia de los extractos de Schinus molle en comparación con el antioxidante sintético BHT, para retrasar la oxidación de algunos aceites vegetales. Los resultados del presente estudio mostraron que los extractos de frutas y hojas de Schinus molle presentan potencial para ser utilizados como antioxidantes en aceites vegetales, presentando actividades basadas en métodos probados, DPPH y ABTS. Los extractos también se caracterizaron por la presencia de compuestos fenólicos determinados mediante el método de Folin Ciocalteau y por cromatografía líquida de alta resolución (HPLC). La acción de los extractos como 
antioxidantes naturales se evidenció en aceites vegetales de chía (Salvia hispanica) y maní (Arachis hypogaea) por el método Rancimat. Se observó que los aceites aumentan la resistencia a la oxidación cuando se le incorporan extractos de Schinus molle, aumentando el periodo de inducción en más de tres horas (de 19,5 a 22,9 horas) del aceite de cacahuete con una concentración de extracto del 2,5\%. El extracto de fruta fue más eficiente en retrasar la oxidación del aceite de chia, prolongando el período de inducción de este aceite en más de una hora con una concentración del 2,5\% (de 3,1 a 4,3 horas). De acuerdo con los resultados, los extractos de Schinus molle tienen propiedades favorables para un posible uso como un aditivo inhibidor del proceso de oxidación de los aceites vegetales ensayados.

PALABRAS CLAVE: Aceites vegetales; Estabilidad oxidativa; Extractos hidroalcohólicos; Rancimat; Schinus molle

ORCID ID: Volpini-Klein AFN https://orcid.org/0000-0002-3148-5106, Silva CAA https://orcid.org/0000-0001-90701182, Fernandes SSL https://orcid.org/0000-0001-8525-404X. Nicolau CL https://orcid.org/0000-0002-0030-1634, Cardoso CAL https://orcid.org/0000-0002-4907-0056, Fiorucci AR https://orcid.org/0000-0001-9441-1561, Simionatto E https://orcid.org/0000-0003-2029-8003

Citation/Cómo citar este artículo: Volpini-Klein AFN, Silva CAA, Fernandes SSL, Nicolau CL, Cardoso CAL, Fiorucci AR, Simionatto E. 2020. Effect of leaf and fruit extracts of Schinus molle on oxidative stability of some vegetables oils under accelerated oxidation. Grasas Aceites 71 (3), e363. https://doi.org/10.3989/gya.0456191

Copyright: (C2020 CSIC. This is an open-access article distributed under the terms of the Creative Commons Attribution 4.0 International (CC BY 4.0) License.

\section{INTRODUCTION}

Lipid oxidation is one of the major changes affecting oils and fats, as well as the foods that contain them. Oxidative lipid degradation is one of the most critical factors affecting the shelf-life and quality parameters of a product, rendering it sensorially unacceptable, as well as causing damage to cell membranes, enzymes, proteins, and partial destruction of fat-soluble vitamins, which may pose a direct threat to human health (Da Silva and Jorge, 2014; Malheiros et al., 2013).

In recent decades, synthetic antioxidants such as butylhydroxyanisole (BHA), butylhydroxytoluene (BHT), tert-butylhydroquinone (TBHQ) and propyl gallate $(\mathrm{PG})$ have been extensively used for retarding lipid oxidative degradation, due to their high stability and low cost. However, insecurity regarding the use of synthetic antioxidants has increased globally. Its effects on health have been questioned, since the prolonged use of these antioxidants can contribute to the emergence of diseases (Yang et al., 2015; Bodoira et al., 2017; Cordeiro et al., 2013).

The search for natural antioxidants capable of retarding food oxidation and replacing synthetic food additives has been of interest to the scientific community because they help inhibit fatty acid oxidation, participate in disease prevention, and are easily obtained from vegetables. In this sense, extensive research has been undertaken with the purpose of finding natural products with antioxidant activity which could replace synthetic ones or make associations among them, with the intention of diminishing their quantities in foods (Bodoira et al., 2017; Taghvaei et al., 2014).

Lipid oxidation can be generally evaluated by the oxidative stability index, which is one of the most important factors affecting the application and storage performance of oils. Rancimat is a thermally accelerated technique for the determination of oxidative stability, through of the determination of the induction period (IP). The Rancimat analysis aimed to measure the induction period (IP) by detecting the formed volatile acids during the oil's oxidation(Mathäus, 1996). The method has been popular around the world because of its ease of handling and reproducibility of results, and has been adopted by various standards including AOCS Cd 12b-92, ISO 6886 and EN14112. Under the conditions of Rancimat (accelerated oxidation test), the higher the IP value, the more stable the edible oil ( $\mathrm{Li}$ et al., 2019).

S. molle L. (Anacardiaceae) is a species found in tropical and subtropical regions of the world, and is commonly known as aroeira-parsley, pepper spray, and anacauite, among others. Its fruits and leaves are used in traditional medicine because they have several properties related to their high contents of terpenic and phenolic compounds produced by the secondary metabolism of the plant (Hosni et al., 2011; Bras et al., 2010). Research has shown several biological activities for the essential oil and extracts of the leaves and fruits of $S$. molle. In addition to biological activities, studies show a variation in the composition of the major components of the essential oil of this species. S. molle extracts have been used as topical antiseptic, antibacterial, antiviral, antifungal, anti-inflammatory, antioxidant, antitumor, astringent, antispasmodic, digestive stimulant, tonic, wound healing, diuretic, analgesic, stimulant and antidepressant (Salem et al., 2016).

The oils of chia (Salvia hispanica) and peanut (Arachis hypogaea) have different oxidative stability characteristics. The oxidative stability of chia oil 
is relatively low and studies have been developed to improve this oil's behavior (Bodoira et al., 2017). Peanut oil is one of the most stable vegetable oils against oxidation. This is partly due to its fatty acid composition, which is low in polyunsaturated fatty acids (O'Keefe, 1993).

Considering the indications of problems that may be caused by the consumption of synthetic antioxidants and the increasing number of consumers who opt for value-added foods, the present study aimed to characterize the phenolic compounds and antioxidant activity of the leaf and fruit extracts of $S$. molle in order for them to be used as natural antioxidants in edible oils. The purpose of this study was to evaluate the effectiveness of the extracts of $S$. molle, compared to the synthetic antioxidant butylhydroxyltoluene (BHT), in retarding the oxidation of the vegetable oils chia and peanut.

\section{MATERIALS AND METHODS}

\subsection{Chemicals}

Ethanol, methanol, glacial acetic acid, sodium acetate, acetonitrile, caffeic acid, ferulic acid, gallic acid, rosmarinic acid, p-coumaric acid, rutin, quercetin luteolin, apigenin, 2,2-diphenyl1-picrylhydrazyl (DPPH), ( \pm ) -6-Hydroxy-2,5,7,8tetramethylchromane-2-carboxylic acid (Trolox), ethyl benzothiazoline-6-sulfonic acid diammonium 2,2'-azino-bis (ABTS), sodium chloride, aluminun chloride, sodium acetate, 7-Hydroxy-3Hphenoxazin-3-one-10-oxide sodium salt (Resazurin sodium salt), sodium carbonate, potassium persulfate and butylhydroxytoluene (BHT) were all purchased from Sigma-Aldrich, São Paulo - SP, Brazil.

\subsection{Oil extraction}

For the extraction of the oils, peanut grains of the Virginia type (Arachis hypogaea L.) and black chia seeds (Salvia hispanica) were used. The samples of peanut and chia kernels were crushed in a blender and submitted to extraction with hexane for $8 \mathrm{~h}$ in Soxhlet. At the end of the extraction period, the solvent was removed in a rotary evaporator at $50{ }^{\circ} \mathrm{C}$. This procedure was performed several times until approximately $1 \mathrm{~L}$ of oil was obtained.

\subsection{Degumming of oil with water}

$100 \mathrm{~g}$ of oil (chia and penut) and $3 \mathrm{~mL}$ of heated water $\left(70^{\circ} \mathrm{C}\right)$ were added to 250 -mL beakers. The mixtures were stirred for $30 \mathrm{~min}$, and then left to decant. The precipitate was removed, and the oil was filtered off in anhydrous sodium sulfate (Araújo et al., 2014). The degumming process was performed in triplicate for further analysis.

\subsection{Plant material}

Leaves and fruits of $S$. molle were collected in Naviraí-MS, Brazil, in June, 2016. The collected material collected was dried in a place with low luminosity and humidity, at $35^{\circ} \mathrm{C}$ for 5 days, and kept at room temperature for further processing. The voucher specimen was deposited in the Herbarium of the Faculty of Biological Sciences of the Federal University of Grande Dourados - UFGD (voucher no. 5505).

\subsection{Preparation of plant extracts}

To prepare the extracts for the ultrasound technique, $2 \mathrm{~g}$ of crushed material were used, and $20 \mathrm{~mL}$ of a $50 \%(\mathrm{v} / \mathrm{v})$ ethanol/water solution were placed in an ultrasonic bath for 60 minutes at $30^{\circ} \mathrm{C}$, followed by centrifugation $\left(2000 \mathrm{rpm}\right.$ for $20 \mathrm{~min}$ at $\left.4{ }^{\circ} \mathrm{C}\right)$. The supernatants were recovered, and the solvents (water/ethanol) were evaporated to obtain a crude extract (Hammi et al., 2015). The extraction was performed in triplicate.

\subsection{Total flavonoids}

Total flavonoids were determined spectrophotometrically according to Djeridane et al., 2006. Briefly, $1000 \mu \mathrm{L}$ of $2 \% \mathrm{AlCl}_{3}$ methanol solution were added to $1000 \mu \mathrm{L}$ of the plant aqueous extract diluted in water $(1 \mathrm{mg} / \mathrm{mL})$. After incubation for $15 \mathrm{~min}$, the absorbance of the final mixture was read by spectrophotometer (FENTO 700 PLUS) $(\lambda=430 \mathrm{~nm})$. This method is based on the formation of a flavonoid-aluminum complex, with maximum absorption at $430 \mathrm{~nm}$. Rutin (Sigma-Aldrich, USA) was used as a standard at concentrations varying from 1 to $50 \mu \mathrm{g} / \mathrm{mL}, \mathrm{r}^{2}=0.9996$. The flavonoid content was expressed in mg per $\mathrm{g}$ of rutin equivalent. All tests were performed in triplicate.

\subsection{Content of phenolic compounds}

Total phenolics were determined according to the Folin-Ciocalteu's reagent method (Djeridane et al., 2006). Briefly, $100 \mu \mathrm{L}$ of the aqueous extract solution $(1 \mathrm{mg} / \mathrm{mL})$ were added to $1000 \mu \mathrm{L}$ of ultrapure water and $500 \mu \mathrm{L}$ of the Folin-Ciocalteu's reagent $(1 / 10)$ in water. After $1 \mathrm{~min} 1500 \mu \mathrm{L}$ of $\mathrm{Na}_{2} \mathrm{CO}_{3}(20 \%$ w/v $)$ were added. The final mixture was shaken and then incubated for 2 hours in the dark. The absorbance was read by spectrophotometer (FENTO 700 PLUS) $(\lambda=760 \mathrm{~nm})$. Gallic acid (Sigma-Aldrich, USA) was used as a standard at concentrations varying from 5 to $1000 \mu \mathrm{g} / \mathrm{mL}$, $\mathrm{r}^{2}=0.9992$. The result was expressed in $\mathrm{mg}$ of gallic acid per g of dry weight of aqueous extract. All tests were performed in triplicate. 


\subsection{HPLC analysis}

The extracts obtained from the samples were analyzed in an analytical LC (LC-6AD, Shimadzu, Kyoto, Japão) system with a photodiode array detector (PDA) monitored at $\lambda=200-800 \mathrm{~nm}$ (Shahidi and Ambigaipalan, 2015). The column was an ODS HYPERSIL (C-18, $150 \mathrm{~mm} \times$ 4,6 mm, Thermo Electron Corporation); the flow rate and the injected volume were set at $1.0 \mathrm{~mL} / \mathrm{min}$ and $20 \mu \mathrm{L}$, respectively. All chromatographic analyses were performed at $25^{\circ} \mathrm{C}$. The binary mobile phase was water with $6 \%$ acetic acid, and $2 \mathrm{mM}$ sodium acetate (eluent A) and acetonitrile (eluent B). The following gradient was applied: 0 min $5 \% \mathrm{~B}, 20 \mathrm{~min}, 15 \% \mathrm{~B}$, $30 \mathrm{~min}, 60 \% \mathrm{~B}, 40 \mathrm{~min} 100 \%$ B. Standards of caffeic acid, ferrulic acid, rosmarinic acid, $p$-coumaric acid, rutin, quercetin, luteolin and apigenine were prepared in methanol-water in the concentration of $1000 \mu \mathrm{g} / \mathrm{mL}$. The extracts were prepared in concentrations of $1000 \mu \mathrm{g} / \mathrm{mL}$. The compound concentrations were determined by external calibration after dilutions were acquired in the range of $1-50 \mu \mathrm{g} / \mathrm{mL}$. All tests were performed in triplicate.

\subsection{Evaluation of antioxidant activity}

\subsubsection{DPPH assay}

The activity of free radical removal of the extracts was evaluated by the modified 2,2-diphenyl-1-picrylhydrazyl (DPPH) assay and the total antioxidant capacity equivalent to Trolox (TEAC) (Simionatto et al., 2007; Rufino et al. 2007). A stock solution of DPPH in $0.004 \%$ methanol was prepared and $50 \mu \mathrm{L}$ of the concentrations $1.25 \mathrm{mg} / \mathrm{mL}, 0.625 \mathrm{mg} / \mathrm{mL}$ and $0.312 \mathrm{mg} / \mathrm{mL}$ of $S$. molle extracts were added to $5 \mathrm{~mL}$ of the DPPH solution. After 30 minutes of incubation in a dark environment and at room temperature, the absorbance was analyzed at wavelength $517 \mathrm{~nm}$. Routine was used as standard. The inhibition of free radical DPPH (I\%) was calculated according to the equation:

$$
\left.\mathrm{I} \%=\left[\mathrm{A}_{\mathrm{a}}-\mathrm{A}_{\mathrm{b}}\right) /\left(\mathrm{A}_{\mathrm{a}}\right)\right] .100
$$

Where, $\mathrm{Aa}$ is the control Absorbance; $\mathrm{Ab}$ is the absorbance of the reaction. The concentration of the extract $(\mu \mathrm{g} / \mathrm{mL})$ giving $50 \%$ inhibition of DPPH radicals (IC50) was obtained by linear regression analysis interpolation.

The total antioxidant capacity equivalent to Trolox (TEAC) was performed using a standard curve constructed at $2000 \mu \mathrm{M}, 1500 \mu \mathrm{M}, 1000 \mu \mathrm{M}, 500 \mu \mathrm{M}$ and $100 \mu \mathrm{M}$ Trolox concentrations, using the $0.004 \%$ DPPH solution as reagent, and the concentrations of $5 \mathrm{mg} / \mathrm{mL}, 2.5 \mathrm{mg} / \mathrm{mL}, 1.25 \mathrm{mg} / \mathrm{mL}, 0.625 \mathrm{mg} / \mathrm{mL}$ and $0.312 \mathrm{mg} / \mathrm{mL}$, and the values obtained were expressed in $\mu \mathrm{Mtrolox} / \mathrm{g}$ crude extract and analyzed.

\subsubsection{ABTS assay}

The activity of elimination of free radical extracts was also determined by ABTS assay, where the percentage of inhibition was evaluated according to the methodology described by Re et al., (2007) and by the method described by Rufino et al., (2007). The ABTS radical was prepared from the reaction of 140 $\mathrm{mM}$ potassium persulfate with $7 \mathrm{mM}$ ABTS and stored in the dark at room temperature for 16 hours and diluted in $95 \%$ ethyl alcohol until the absorbance value of $0.700 \pm 0.020$ at wavelength $734 \mathrm{~nm}$.

To assess the percentage inhibition of antioxidant activity, aliquots of $30 \mu \mathrm{L}$ of sample at concentrations of $1.25 \mathrm{mg} / \mathrm{mL}, 0.625 \mathrm{mg} / \mathrm{mL}$ and $0.312 \mathrm{mg} / \mathrm{mL}$ were transferred to test tubes and added with ABTS. After 6 minutes of reaction in the dark at room temperature, the absorbances were analyzed at $734 \mathrm{~nm}$ using ethanol as white and routine as standard. The inhibition of free radical ABTS (I\%) was calculated according to the equation:

$$
\left.\mathrm{I} \%=\left[\mathrm{A}_{\mathrm{a}}-\mathrm{A}_{\mathrm{b}}\right) /\left(\mathrm{A}_{\mathrm{a}}\right)\right] .100
$$

The extract concentration $(\mu \mathrm{g} / \mathrm{mL})$ providing $50 \%$ inhibition of the DPPH radicals (IC50) was obtained by linear regression analysis interpolation.

The total antioxidant capacity equivalent to Trolox (TEAC) was performed using a standard curve constructed at $2000 \mu \mathrm{M}, 1500 \mu \mathrm{M}, 1000 \mu \mathrm{M}$, $500 \mu \mathrm{M}$ and $100 \mu \mathrm{M}$ Trolox concentrations, using the ABTS radical as reagent, and the extracts at concentrations of $5 \mathrm{mg} / \mathrm{mL}, 2.5 \mathrm{mg} / \mathrm{mL}, 1.25 \mathrm{mg} / \mathrm{mL}$, $0.625 \mathrm{mg} / \mathrm{mL}$ and $0.312 \mathrm{mg} / \mathrm{mL}$. The values obtained were expressed in $\mu \mathrm{M}$ trolox/g crude extract.

\subsection{Oil samples enriched with hydroalcoholic extracts (leaves and fruits) of $S$. molle and BHT}

Samples of chia and peanut oils enriched with the hydroalcoholic extracts of leaves and fruits of $S$. molle were prepared to reach concentrations of 0.62 and $2.5 \%$ (extract in oil). The extracts were added directly to the oils, followed by slow stirring until dissolution. Samples of chia and peanut oils were also enriched with the synthetic antioxidant BHT at concentrations of 0.62 and 2.5\% (BHT in oil). BHT was added directly to the oils, followed by slow stirring until dissolution.

\subsection{Oxidative stability (Rancimat test)}

The oxidative stability index (OSI) values were expressed as induction period (IP) in hours and determined according to the AOCS Official Method Cd 12b-92 (1993), measured by the Rancimat apparatus (Metrohm, model 893 Professional Rancimat), which is based on the continuous measurement of the electric conductivity of the distilled water in 
which the volatile product degradations are collected and absorbed, resulting in increased conductivity during the assay. The determination was made at $110^{\circ} \mathrm{C}$ with a $20 \mathrm{~L} / \mathrm{h}$ air flow, using $3.0 \pm 0.1 \mathrm{~g}$ of the sample and $60 \mathrm{~mL}$ distilled water in flasks containing electrodes. Water conductivity was monitored in order to determine the IP, calculated by the software StabNet (Metrohm, Switzerland) for the time of maximum value of the second derivative of the conductivity curve in function of the time.

\subsection{Statistical analysis}

The results are shown and expressed in terms of the mean and standard deviations. Significant differences were calculated using ANOVA in combination with Duncan's test with a significance level of $\alpha=0.05$.

\section{RESULTS AND DISCUSSION}

\subsection{Characterization of hydroalcoholic extracts of the leaves and fruits of $S$. molle}

The hydroalcoholic extracts of the leaves and fruits of $S$. molle were obtained in yields of $16.3 \pm$ $0.6 \%$ and $12.7 \pm 0.3 \%$, respectively. The extracts were characterized spectrophotometrically for the presence of phenolic compounds and flavonoids. The highest contents of these phenolic compounds were found in the hydroalcoholic extract of the leaves. (Table 1).

The hydroalcoholic extracts of the leaves and fruits of $S$. molle were analyzed by HPLC with standards of authentic compounds. Initially, 8 chromatographic peaks were identified in the analysis of the leaf extract and 5 peaks in the fruit extract. Based on their retention times and their comparison with standards, it was possible to identify 7 substances in the leaf extract (vanilic acid, sinapic acid, caffeic acid, ferrulic acid, rutin, quercitin and apigenin) and 3 substances in the fruit extract (ferrulic acid, rutin and quercitin). The contents of these compounds in the extracts and their chromatographic profiles are shown in Table 2 and Figures 1-2, respectively.

TABLE 1. Contents of phenolic compounds and

flavonoids in the hydroalcoholic extracts of the leaves and fruits of $S$. molle (in $\mathrm{mg} / \mathrm{g} \pm \mathrm{SD}$ ).

\begin{tabular}{lcc}
\hline & Phenolic compounds & Flavonoids \\
\hline Fruits & $127.9 \pm 0.1^{\mathrm{b}}$ & $41.2 \pm 0.2^{\mathrm{b}}$ \\
Leaves & $601.1 \pm 0.6^{\mathrm{a}}$ & $193.9 \pm 0.3^{\mathrm{a}}$ \\
\hline
\end{tabular}

Data are shown as mean \pm standard deviation $(\mathrm{SD})$. Different letters in the same columns represent significant differences ( $\mathrm{p}$ $<0.05)$, the same letters do not differ significantly. The Duncan test $(\mathrm{p}<0.05)$ was used for the comparison of means. All experiments were carried out in triplicate.
Along with the identification of these compounds the presence of 3 hydroxycinnamic acids (caffeic acid, ferulic and sinapic), a hydroxybenzoic acid (vanillic acid) and 3 flavonoids (rutin, quercetin and apigenin) can be observed.

Phenolic acids behave as antioxidants, due to the reactivity of their phenol moiety (hydroxyl substituent on the aromatic ring) (Shahidi and Ambigaipalan, 2015). All these phenolic acids (hydroxycinnamic and hydroxybenzoic acids) are

TABLE 2. Compounds identified by liquid chromatography (HPLC) in the hydroalcoholic extracts of the leaves and fruits of $S$. molle.

\begin{tabular}{lclcc}
\hline RT (min) & Peak & Compound & $\begin{array}{c}\text { Fruit Extract } \\
\text { mg/g } \pm \text { SD }\end{array}$ & $\begin{array}{c}\text { Leaf extract } \\
\text { mg/g } \pm \text { SD }\end{array}$ \\
\hline 4.98 & 1 & Vanilic acid & - & $45.3 \pm 0.2^{\mathrm{a}}$ \\
6.03 & 2 & Caffeic acid & - & $20.9 \pm 0.1^{\mathrm{a}}$ \\
8.96 & 3 & Ferulic acid & $23.7 \pm 0.1^{\mathrm{b}}$ & $92.7 \pm 0.4^{\mathrm{a}}$ \\
13.45 & 4 & Sinapic acid & - & $14.7 \pm 0.1^{\mathrm{a}}$ \\
21.64 & 5 & Rutin & $37.3 \pm 0.3^{\mathrm{a}}$ & $26.3 \pm 0.2^{\mathrm{b}}$ \\
24.32 & 6 & Quercetin & $36.9 \pm .0 .2^{\mathrm{b}}$ & $37.8 \pm 0.1^{\mathrm{a}}$ \\
25.67 & 7 & Apigenina & - & $11.3 \pm 0.1^{\mathrm{a}}$ \\
\hline
\end{tabular}

Data are shown as mean \pm standard deviation (SD). Different letters in the same line represent significant differences $(\mathrm{p}<0.05)$, the same letters do not differ significantly. The Duncan test $(\mathrm{p}<0.05)$ was used for comparison of means. All experiments were carried out in triplicate. RT: retention time.
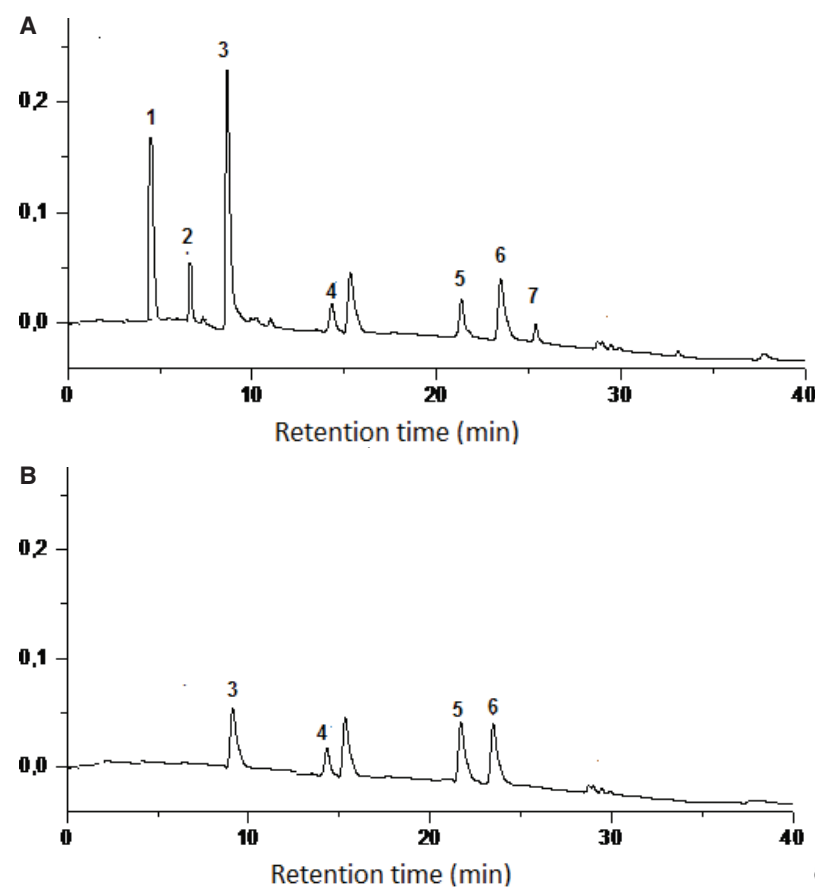

FIGURE 1. Chromatographic profile $(280 \mathrm{~nm})$ of the hydroalcoholic extracts of the leaves (A) and fruits (B) of S. molle. 


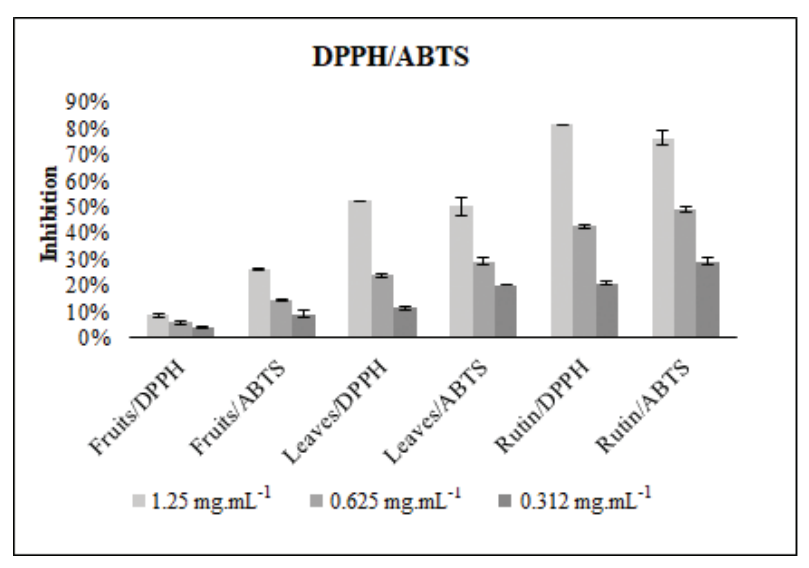

The Duncan test $(\mathrm{p}<0.05)$ was used for the comparison of means. All experiments were carried out in triplicate.

Figure 2. Comparison of the antioxidant potential of the extracts with different concentrations of rutin $(0.312,0.625$ and $1.25 \mathrm{mg} \cdot \mathrm{mL}^{-1}$ ) by the DPPH and ABTS methods.

compounds with important antioxidant activity and are cited as important functional components. Phenolic acids, known to serve as multipurpose bioactive compounds, are distributed throughout the plant kingdom. Many of them are an integral part of the human diet and are also consumed as medicinal preparations. Some health-protective effects of phenolic compounds have been attributed to their antioxidant, antimutagenic, anticarcinogenic, antiinflammatory, antimicrobial and other biological properties (Xu et al., 2008).

\subsection{Evaluation of the antioxidant activity of hydroalcoholic extracts}

The radical scavenging activity of the extracts examined is presented in Table 3. The extracts were evaluated by methods using DPPH and ABTS. According to the results, a similar behavior occurred with the leaf and fruit extracts in the two methods used. The hydroalcoholic extract from the leaves presented better activity, reaching IC50 values of $11.7 \pm$ $0.8 \mu \mathrm{g} / \mathrm{mL}$ and $12.9 \pm 1.1 \mu \mathrm{g} / \mathrm{mL}$, for the assays with DPPH and ABTS, respectively (Table 3). The tests were developed using rutin as the control. This flavonoid has been previously described as having excellent antioxidant activity and as being widely found as a natural plant product (D'andrea, 2015). Rutin showed IC50 values of 7.7 and $7.1 \mu \mathrm{g} / \mathrm{mL}$ in the DPPH and ABTS tests, respectively. Thus, due to its significant presence in the leaf extract, it can be inferred that this flavonoid contributes to the good activity of the extract. Due to the health promoting effects of rutin, an increased interest in their utilization in food systems has arisen (Prikryl et al., 2018).

Figure 2 shows comparisons among the concentrations of $0.312,0.625$ and $1.25 \mathrm{mg} / \mathrm{mL}$ of fruit and
TABLE 3. IC50 values (in $\mu \mathrm{g} / \mathrm{mL} \pm \mathrm{SD}$ ) of the hydroalcoholic extracts (by the ABTS and DPPH methods) of leaves and fruits of $S$. molle.

\begin{tabular}{lccc}
\hline & Fruits & Leaves & Rutin $^{\mathrm{a}}$ \\
\hline DPPH & $23.1 \pm 2.8^{\mathrm{b}}$ & $11.7 \pm 0.8^{\mathrm{c}}$ & $7.1 \pm 0.8^{\mathrm{d}}$ \\
ABTS & $98.8 \pm 3.5^{\mathrm{b}}$ & $12.9 \pm 0.6^{\mathrm{c}}$ & $7.7 \pm 0.5^{\mathrm{d}}$ \\
\hline
\end{tabular}

Data are shown as mean \pm standard deviation (SD). Different letters in the same lines represent significant differences $(p<0.05)$, the same letters do not differ significantly. The Duncan test $(p<0.05)$ was used for the comparison of means. All experiments were carried out in triplicate. IC50: concentration that inhibits $50 \%$ of DPPH/ABTS radicals. a indicates the Standard.

TABLE 4. TEAC values (in $\mu \mathrm{mol} / \mathrm{g} \pm \mathrm{SD}$ ) by the ABTS and DPPH methods for the hydroalcoholic extracts of fruits and leaves of $S$. molle.

\begin{tabular}{lcc}
\hline Extracts & ABTS & DPPH \\
\hline Fruits & $383.3 \pm 19.2^{\mathrm{c}}$ & $505.0 \pm 3.2^{\mathrm{c}}$ \\
Leaves & $926.4 \pm 39.7^{\mathrm{b}}$ & $1546.6 \pm 24.5^{\mathrm{b}}$ \\
Rutin $^{\mathrm{d}}$ & $1510.0 \pm 32.6^{\mathrm{a}}$ & $2953.5 \pm 25.9^{\mathrm{a}}$ \\
\hline
\end{tabular}

Data are shown as mean \pm standard deviation (SD). Different letters in the same column represent significant differences $(\mathrm{p}<0.05)$, the same letters do not differ significantly. The Duncan test $(\mathrm{p}<0.05)$ was used for the comparison of means. All experiments were carried out in triplicate. ${ }^{\mathrm{d}}$ indicates the standard. TEAC: Trolox equivalent antioxidant capacity.

leaf hydroalcoholic extracts and the flavonoid rutin. Clearly, the greater inhibition power of leaf extracts is observed at the concentration of $1.25 \mathrm{mg} / \mathrm{mL}$, with inhibitions of $52 \%$ and $50 \%$ of the DPPH and ABTS radicals, respectively. At this same concentration $(1.25 \mathrm{mg} / \mathrm{mL})$, the DPPH and ABTS radicals are inhibited by rutin at levels of 80 and $76 \%$, respectively.

The results of the antioxidant activity by the ABTS and DPPH methods were also expressed as total antioxidant capacity equivalents to Trolox (TEAC values). According to Table 4, it was observed that in the antioxidant test by the DPPH radical capture method, the leaf extract of S. molle had the highest antioxidant capacity, with TEAC values of $1546.6 \pm 24.5 \mathrm{mM}$ Trolox/g of hydroalcohol extract. The highest value was also obtained in the test with the method ABTS $(926.4 \pm 39.7 \mathrm{mM}$ Trolox/g of hydroalcohol extract) for the hydroalcoholic extract of leaves. In the two methods of TEAC determination, the flavonoid rutin was used as control and demonstrated results that guarantee safety in the measurements. These results are in agreement with the contents of phenolic compounds, where also the samples from leaves were the ones with the highest contents of these components. In addition, several studies have reported that the relationship between antioxidant activity and high phenolic compound content is proportional (Alamed et al., 2009). 
TABLE 5. Oxidative stability (Induction Period) of peanut and chia oils at different concentrations of $S$. molle extracts.

\begin{tabular}{lccccc}
\hline & \multicolumn{3}{c}{ Induction Period (hours) } \\
\cline { 2 - 3 } \cline { 5 - 6 } Treatments & \multicolumn{2}{c}{ Peanut oil } & & \multicolumn{2}{c}{ Chia oil } \\
\cline { 2 - 3 } \cline { 5 - 6 } & $\mathbf{0 . 6 2} \%$ & $\mathbf{2 . 5 \%}$ & & $\mathbf{0 . 6 2} \%$ & $\mathbf{2 . 5 \%}$ \\
\hline Oil with leaf extract & $22.35 \pm 0.38^{\mathrm{a}}$ & $22.90 \pm 0.35^{\mathrm{a}}$ & & $3.37 \pm 0.12^{\mathrm{c}}$ & $3.47 \pm 0.16^{\mathrm{c}}$ \\
Oil with fruit extract & $21.28 \pm 0.32^{\mathrm{b}}$ & $22.51 \pm 0.33^{\mathrm{a}}$ & & $3.54 \pm 0.07^{\mathrm{b}}$ & $4.27 \pm 0.05^{\mathrm{b}}$ \\
Oil with BHT & $>30$ & $>30$ & & $9.13 \pm 0.13^{\mathrm{a}}$ & $12.92 \pm 0.35^{\mathrm{a}}$ \\
Pure oil (control) & $19.50 \pm 0.18^{\mathrm{c}}$ & $19.50 \pm 0.15^{\mathrm{b}}$ & & $3.06 \pm 0.03^{\mathrm{d}}$ & $3.06 \pm 0.03^{\mathrm{c}}$ \\
\hline
\end{tabular}

Data are shown as mean \pm standard deviation (SD). Different letters in the same column represent significant differences $(\mathrm{p}<0.05)$, the same letters do not differ significantly. The Duncan test $(\mathrm{p}<0.05)$ was used for the comparison of means. All experiments were carried out in triplicate. BHT: butylhydroxyltoluene.

\subsection{Antioxidant activity under Rancimat conditions}

After demonstrating significant antioxidant activity, the extracts of $S$. molle (leaves and fruits) were evaluated for the inhibition of oxidation by the Rancimat test in peanut (Arachis hypogeae) and chia (Salvia hispanica) oils. Table 5 demonstrates that the hydroalcoholic extract of the leaves of $S$. molle shows better performance for increasing the oxidative stability of peanut oil. This activity of the extract is probably related to the greater diversity of phenolic compounds present in the leaf extract. Among the compounds identified in the leaf (caffeic acid, ferrulic acid, rutin and quercitin), caffeic acid is not present in the fruit extract.

The induction period of the control sample of peanut oil was $19.50 \mathrm{~h}$, while the additive samples of $S$. molle extracts reached $22.90 \mathrm{~h}$. It was observed that the added concentrations of extract $(0.62 \%$ and $2.5 \%$ ) did not show great variation in relation to the change in the induction period. When the extracts of $S$. molle were evaluated for the effect of inhibition of lipid oxidation in chia oil, it was observed that the best performance was with the addition of fruit extracts. The oil with $2.5 \%$ extract showed an increase in the induction period from $3.06 \pm 0.03$ hours (pure oil) to $4.27 \pm 0.05$ hours. The samples added with BHT showed significantly higher results when added in the same proportions $(0.62$ and $2.5 \%)$, increasing the induction periods for peanut and chia oils by more than 30 and 9 hours, respectively. In spite of this great difference, these extracts presented favorable characteristics due to their diversity of compounds and phenolics.

Numerous scientific researchers are focusing their efforts on identifying new sources of natural antioxidants to stabilize plant oils. Some works have already proposed the use of rosemary and sage due to their contents of carnosol and carnosic acid, which are the most common antioxidants found in such vegetable matrices (Esposto et al., 2015). In this context, the present work demonstrates that the extracts of $S$. molle can have a positive effect on the inhibition of the oxidation of oils. It is noteworthy that this oxidation inhibitory effect occurred both in oils with high oxidation resistance and in oils with lower resistance, as shown for peanut and chia oils, respectively.

\section{CONCLUSIONS}

In this work, the Rancimat method was used to evaluate the efficacy of the extracts of $S$. molle as alternative antioxidants for vegetable oils, evaluating the actions of the extracts as inhibitors of lipid oxidation in peanut and chia oils. The leaf extract of $S$. molle showed the highest antioxidant efficiency in the Rancimat method. A possible explanation is the higher concentration of phenolic compounds in this extract, which results in greater protection power when used as an antioxidant. The addition of extracts to vegetable oils is a promising alternative for increasing oxidative stability and inducing the consumption of phytonutrients such as phenolic compounds, and many of these compounds are present in the leaf and fruit extracts of S. molle, which can be exploited for this purpose.

\section{ACKNOWLEDGMENTS}

The authors are grateful to CNPq, CAPES and FUNDECT for the financial support given to this work.

\section{REFERENCES}

Alamed J, Chaiyasit W, McClements DJ, Decker EA. 2009. Relationship between free radical scavenging and antioxidant activity in foods. J. Agric. Food Chem. 57, 2969-2976. https://doi.org/10.1021/jf803436c

AOCS. 1993. Society. Official methods and recommended practices of the American Oil Chemists' Society. Methods Cd 12b-92: Champaign, USA.

Araújo FDS, Araújo IC, Costa ICG, de Moura CVR, Chaves MH, Araújo, ECE. 2014. Study of degumming process and evaluation of oxidative stability of methyl and ethyl biodiesel of Jatropha curcas L. oil from three different 
Brazilian states. Renew. Energy. 71, 495-501. https://doi. org/10.1016/j.renene.2014.06.001

Bodoira RM, Penci MC, Bibotta PD, Martinez ML. 2017. Chia (Salvia hispanica L.) oil stability: Study of the effect of natural antioxidants. LWT - Food Sci. Technol. 75, 107-113. https://doi.org/10.1016/j.lwt.2016.08.031

Bras C, Domínguez S, Codón S, Munetti A, Ferrero A. 2010. Consequences of subcrhronic exposure to ethanolic extract from fruits and leves of $S$. molle var. areia L. in mice. $J$. Ethnopharmacol. 132, 321-327. https://doi.org/10.1016/j. jep.2010.08.035

Cordeiro AMTM, Medeiros ML, Santos NA, Soledade LEB, Pontes LFBL, Souza AL, Queiroz N, Souza AG. 2013. Rosemary (Rosmarinus officinalis L.) extract. J. Therm. Anal. Calorim. 113, 889-895. https://doi.org/10.1007/ s10973-012-2778-4

D'Andrea G. 2015. Quercetin: A flavonol with multifaceted therapeutic applications? Fitoterapia 106, 256-271. https:// doi.org/10.1016/j.fitote.2015.09.018

Djeridane A, Yousfi M, Nadjemi B, Boutassouna D, Stocker P, Vidal N. 2006. Antioxidant activity of some Algerian medicinal plants extracts containing phenolic compounds. Food Chem. 97, 654-660. https://doi.org/10.1016/j. foodchem.2005.04.028

Esposto S, Taticchi A, Di Maio I, Urbani S, Veneziani G, Selvaggini R, Sordini B, Servili M. 2015. Effect of an olive phenolic extract on the quality of vegetable oils during frying. Food Chem. 176, 184-192. https://doi.org/10.1016/j. foodchem.2014.12.036

Formagio ASN, Volobuff CRF, Santiago M, Cardoso CAL, Vieira MDC, Valdevina-Pereira Z. 2014. Evaluation of Antioxidant Activity, Total Flavonoids, Tannins and Phenolic Compounds in Psychotria Leaf Extracts. Antioxidants. 3, 745-757. https://doi.org/10.3390/antiox3040745

Hammi KM, Jdey A, Abdelly C, Majdoub H, Ksouri R. 2015. Optimization of ultrasound-assisted extraction of antioxidant compounds from Tunisian Zizyphus lotus fruits using response surface methodology. Food Chem. 184, 80-89. https://doi.org/10.1016/j.foodchem.2015.03.047

Hosni K, Jemli M, Sziri S, M'rabet Y, Ennigrou A, Sghaier A, Casabianca H, Vulliet E, Brahim NB, Sebei H, 2011. Changes in phytochemical, antimicrobial and free radical scavening activities of the Peruvian pepper tree (S. molle) as influenced by fruit maturation. Ind. Crops Prod. 34, 1622-1628. https://doi.org/10.1016/j.indcrop.2011.06.004

Li X, Li Y, Yang F, Liu R, Zhao C, Jin Q, Wang X. 2019. Oxidation degree of soybean oil at induction time point under Rancimat test condition: Theoretical derivation and experimental observation. Food Res. Int. 120, 756-762. https://doi.org/10.1016/j.foodres.2018.11.036

Lim S, Choib A, Kwona M, Jounga E, Shinb T, Leea S, Kimc N, Kima H. 2019. Evaluation of antioxidant activities of various solvent extract from Sargassum serratifolium and its major antioxidant components. Food Chem. 278, 178-184. https://doi.org/10.1016/j.foodchem.2018.11.058

Malheiros R, Rodrigues N, Manzke G, Bento A, Pereira JÁ, Casal S. 2013. The use of olive leaves and tea extracts as effective antioxidants against the oxidation of soybean oil under microwave heating. Ind. Crops Prod. 44, 37-43. https://doi.org/10.1016/j.indcrop.2012.10.023
Mathäus B. 1996. Determination of the oxidative stability of vegetable oils by rancimat and conductivity and chemiluminescence measurements. J. Am. Oil Chem. Soc. 73, 10391043. https://doi.org/10.1007/bf02523413

O'Keefe SF, Wiley VA, Knauft DA. 1993. Comparison of Oxidative Stability of High- and NormaI-Oleic Peanut Oils. J. Am. Oil Chem. Soc. 70, 489-492. https://doi. org/10.1007/BF02542581

Prikryl J, Hajek T, Svecova B, Salek RN, Cerníkova M, Cervenka L, Bunka F. 2018. Antioxidant properties and textural characteristics of processed cheese spreads enriched with rutin or quercetin: The effect of processing conditions. LWT - Food Sci. Technol. 87, 266-271. https:// doi.org/10.1016/j.lwt.2017.08.093

Re R, Pellegrini N, Proteggente A, Pannala A, Yang M, Rice-Evans C. 1999. Antioxidant activity applying an improved ABTS radical cation decolorization assay. Free Radic. Biol. Med. 26, 1231-1237. https://doi.org/10.1016/ s0891-5849(98)00315-3

Rufino MSM, Alves RE, Brito ES, Morais SM, Sampaio CG, Jiménez JP, Calixto FDS. 2007. Metodologia Científica: Determinação da Atividade Antioxidante Total em Frutas pela Captura do Radical Livre ABTS $^{*+}$. Comunicado Técnico 128. Embrapa, Fortaleza.

Salem MZM, Zayed MZ, Ali HM, Abd El-Kareem MSM. 2016. Chemical composition, antioxidant and antibacterial activities of extracts from Schinus molle wood branch growing in Egypt. J. Wood Sci. 62, 548-561. https://doi. org/10.1007/s10086-016-1583-2

Shahidi F, Ambigaipalan P. 2015. Phenolics and polyphenolics in foods, beverages and spices: Antioxidant activity and health effects - A review. J. Funct. Foods 18, 820-897. https://doi.org/10.1016/j.jff.2015.06.018

Silva A da, Jorge N. 2014. Influence of Lentinula edodes and Agaricus blazei extracts on the prevention of oxidation and retention of tocopherols in soybean oil in an accelerated storage test. J. Food Sci. Tech. 51, 1208-1212. https://doi. org/10.1007/s13197-012-0623-1

Simionatto E, Bonani VFL, Morel AF, Poppi NR, Raposo Júnior JL, Stuker CZ, Pereuzzo GM, Peres MTLP, Hess SC. 2007. Chemical composition and evaluation of antibacterial and antioxidant activities of the essential oil of Croton urucurana Baillon (Euphorbiaceae) stem bark. J. Braz. Chem. Soc. 18, 879-885. https://doi.org/10.1590/ S0103-50532007000500002

Taghvaei M, Jafari SM, Mahoonak AS, Nikoo AM, Rahmanian N, Hajitabar J, Meshginfar N. 2014. The effect of natural antioxidants extracted from plant and animal resources on the oxidative stability of soybean oil. $L W T$ - Food Sci Technol. 56, 124-130. https://doi.org/10.1016/j. lwt.2013.11.009

Xu G, Ye X, Liu D, Ma Y, Chen J. 2008. Composition and distribution of phenolic acids in Ponkan (Citrus poonensis Hort. ex Tanaka) and Huyou (Citrus paradisi Macf. Changshanhuyou) during maturity. J. Food Compos. Anal. 21, 382-389. https://doi.org/10.1016/j.jfca.2008.03.003

Yang Y, Song X, Sui X, Qi B, Wang Z, Li Y, Jiang L. 2016. Rosemary extract can be used as a synthetic antioxidante to improve vegetable oil oxidative stability. Ind. Crops Prod. 80, 141-147. https://doi.org/10.1016/j.indcrop.2015.11.044 